\title{
Effectiveness of combining resistance to Thielaviopsis basicola and Tomato spotted wilt virus in haploid tobacco genotypes
}

\author{
Anna Trojak-Goluch*, Dorota Laskowska, Monika Agacka, Diana Czarnecka, Magdalena Kawka \\ and Anna Czubacka
}

Department of Plant Breeding and Biotechnology, Institute of Soil Science and Plant Cultivation, State Research Institute, ul. Czartoryskich 8, PL-24-100 Pulawy, Poland

\begin{abstract}
Black root rot (BRR) caused by Thielaviopsis basicola as well as Tomato spotted wilt virus (TSWV) are the most serious problems in tobacco growing regions. We crossed the breeding line WGL 3 carrying BRR resistance derived from N.glauca with the line PW-834 the resistance of which to TSWV was transferred from cultivar Polalta. Anthers obtained from $\mathrm{F}_{1}$ hybrid plants were cultured to induce haploids combining resistance to Th. basicola and TSWV. Flow cytometry analysis revealed 242 haploids and 2 spontaneous doubled haploids among regenerants. All haploids were cloned and then evaluated for BRR as well as TSWV resistance. The presence of pathogens was detected by microscopic evaluation of roots or using DAS-ELISA test. Microscopic assessment showed that, 132 haploids had no symptoms of Th. basicola which, together with the absence of symptoms in the $F_{1}$ hybrids, indicated a dominant monogenic mode of inheritance. At the same time only 30 haploids demonstrated resistance to TSWV. SCAR markers associated with TSWV resistance gene detection was applied. The results indicate that small proportion of TSWV-resistant haploids is probably due to the influence of deleterious genes flanking the resistance factor that reduced vitality of gametophytes. Altogether, 24 haploids showed multiple resistance to Th. basicola and TSWV.
\end{abstract}

Key Words: Nicotiana tabacum, black root rot, Tomato spotted wilt virus, multiple resistance, SCAR markers.

\section{Introduction}

Black root rot (BRR) is one of the most severe diseases in areas of intensive tobacco cultivation (Florczak 1991). Yield losses may amount to $50-75 \%$ when growing conditions are not conducive for tobacco growth. The disease is caused by a common soil-borne fungal pathogen of many important crops, including carrot (Punja and Sun 1999), cotton (Rothrock 1992), lupin (Thalmann et al. 2008), clover and especially tobacco Nicotiana tabacum L. (Gayed 1972). The fungus infects main and lateral roots that results in reduced yield and lower leaf quality. The previous studies on BRR control led to the utilization of a single dominant gene from the wild species $N$. debneyi and to its incorporation into a number of varieties starting with the American Burley 49 (Clayton 1969) and now including American and European cultivars of both Burley and Virginia type (Berbec 2006). A separate line of study, by Trojak-Goluch and Berbec (2005) led to the introgression of $N$. glauca-type resistance into the tobacco genome. Several black root rot resistant lines dubbed WGL were selected and evaluated for their agronomic traits (Trojak-Goluch and Berbec 2011).

Communicated by J. Michael Bonman

Received July 11, 2011. Accepted September 8, 2011.

*Corresponding author (e-mail: anngol@iung.pulawy.pl )
Tomato spotted wilt virus (TSWV) is an economically important pathogen that infects over 900 plant species including tobacco (Daughtrey et al. 1997) and is transmitted by at least eight species of thrips. The wide host range and transmission by thrips makes it difficult to control this virus. The most effective way to minimize the damage of TSWV in tobacco would be to grow transgenic resistant cultivars. A serious disadvantage of the transgene-based resistance to TSWV is a negative reception of the so-called "genetic modifications" by the public at large resulting in a total rejection of "genetically modified tobacco" by tobacco leaf merchants and cigarette manufacturers.

An alternative and efficient source of TSWV resistance is a wild relative of tobacco $N$. alata. This species shows resistance to TSWV (Gajos 1981), but is difficult to utilize in breeding programmes because of genetic incompatibility of the species with cultivated $N$. tabacum (Laskowska and Berbec 2005). Based on this source of resistance a breeding cultivar Polalta with a single dominant gene has been developed (Gajos 1981, Yancheva 1990). The cultivar is completely resistant to TSWV but completely not accepted by growers. When it is crossed with susceptible cultivars morphological deformations, including thickened and ribbonshaped leaves, and irregular venation appear in the resulting progeny and in successive segregating generations (Laskowska and Berbec 2010, Moon and Nicholson 2007). 
It is still a challenge to utilize the naturally introgressed resistance in Polalta. Progress has been made in recent years when doubled haploid lines were derived from the hybrid of Polalta $\times$ Wislica (Laskowska and Berbec 2010). The obtained DH lines PW-834 and PW-900 of $\mathrm{R}_{2}$ and $\mathrm{R}_{3}$ generations showed near-correct morphology and high resistance to TSWV.

A more durable and broader spectrum of resistances in one breeding line or cultivar is a desired goal in tobacco breeding for resistance programmes. Gene pyramiding has been reported for tobacco lines obtained from conventional hybridizing of two PVY resistant lines: the stable transgenic line MN 944 LMV carrying the coat protein gene of Lettuce mosaic virus and the BPA line with $N$. africana-type resistance (Czubacka and Doroszewska 2010). An important potential aid in generating improved usable germplasm in tobacco is provided by the use of in vitro cultures to produce androgenetic haploids and doubled haploids. The method resulted in the development of doubled haploid lines which combined satisfactory agronomic performance with resistances to Tobacco mosaic virus, Phytophthora parasitica and Pseudomonas syringe (Walker and Aycock 1994), PVY (Hamada et al. 2001) or with resistance to lodging (Menchey and Aycock 1998). Combining resistance to Tobacco mosaic virus, Pseudomonas syringae pv. tabaci and Phytophthora parasitica var. nicotianae in dihaploid lines of tobacco has been reported (Walker and Aycock 1994).

To obtain a cultivar with a high level of protection against Th. basicola and TSWV an attempt was made to combine the $N$. glauca-derived resistance to Th. basicola with resistance to TSWV derived from cv. Polalta. To this end, appropriate resistant lines were hybridized conventionally and male gametophytes were induced from the anthers of the resulting $F_{1}$ hybrids. The underlying assumption was that screening for resistance of anther derived haploids based on biological and serological tests combined with markerassisted analysis would enable selection of genotypes resistant to both Th. basicola and TSWV.

\section{Materials and Methods}

\section{Starting plant material}

The starting plant material was as follows: 1) WGL 3, inbred line nearly isogenic to the widely cultivated Polish cultivar Wislica with Nicotiana glauca-type resistance to Thielaviopsis basicola (Trojak-Goluch and Berbec 2011); 2) PW-834, inbred line of recognized complete resistance to TSWV derived from cultivar Polalta (Laskowska and Berbec 2010); 3) the $\mathrm{F}_{1}$ hybrid from crossing WGL $3 \times \mathrm{PW}$ 834 ; 4) Wislica — standard flue cured variety, susceptibility check in Th. basicola and TSWV resistance tests; 5) Polalta - air-cured tobacco variety with resistance to TSWV derived from $N$. alata (Gajos 1981), resistance check in TSWV tests; 6) K326-American standard flue-cured variety, susceptibility check in molecular tests.

\section{Bioassay for black root}

Plants screened for black root rot resistance were planted in the greenhouse, at the five-leaf stage, into plastic pots filled with peat medium inoculated with culture of Th. basicola. A pathogenic culture of Th. basicola was isolated from diseased tobacco roots as described earlier by Trojak-Goluch and Berbec (2005). The fungal bioassay was conducted using the method of Samek and Jankowski (1987). Inoculum suspension density was about 10,000 spores per 1 gram of peat. Plants were grown under the following conditions: $22^{\circ} \mathrm{C}$ during daytime and $18^{\circ} \mathrm{C}$ at night. The symptoms caused by fungal infection were scored after 30 days. The roots were rated, first by visual observation and subsequently by microscopic evaluation. Forty individuals of the inbred lines WGL 3 and PW-834, the $F_{1}$ hybrid population were tested as well as the susceptible cultivars Wislica and Polalta.

\section{Tests for Tomato spotted wilt virus resistance}

The virus used for resistance screening was isolated from plants of cv. Wislica that grew on tobacco fields in western Poland and showed systemic symptoms of TSWV infection. Inoculum was prepared as follows: fresh leaves were ground in phosphate buffer $\left(9.078 \mathrm{~g} / 1 \quad \mathrm{KH}_{2} \mathrm{PO}_{4}\right.$ and $11.867 \mathrm{~g} / \mathrm{l}$ $\mathrm{Na}_{2} \mathrm{HPO}_{4}$ ) with the addition of $0.5 \%$ mercapthoethanol (Tsakiridis and Gooding 1972). The proportion of leaves to buffer was $1 \mathrm{~g}$ tissue to $10 \mathrm{ml}$ of buffer. Virus was passed to six-leaved plants using mechanical inoculation. Plants were kept in a greenhouse at $20-25^{\circ} \mathrm{C}$ with a 16 -h photoperiod. The plants were judged, based on the disease symptoms as well as on DAS-ELISA tests as described by Clark and Adams (1977), using polyclonal antiserum (BIOREBA AG, Switzerland). Resistance test included forty plants of the inbred lines WGL 3 and PW-834, $\mathrm{F}_{1}$ hybrids and 20 plants of each standard: susceptible cv. Wislica and resistant Polalta.

\section{Haploids induction, selection and propagation}

Androgenetic haploids were induced from the anthers of the $\mathrm{F}_{1}$ hybrid WGL $3 \times \mathrm{PW}-834$. Collecting the flower buds from the greenhouse-grown plants, sterilization procedures, culture media and conditions for the induction of androgenetic development and for the rooting of anther-emerged plantlets followed the protocol of Nitsch and Nitsch (1969). Once rooted, the anther-derived plants were verified for ploidy level using flow cytometry. In order to isolate the nuclei for cytometric analysis leaf tissue $\left(1 \mathrm{~cm}^{2}\right)$ was chopped in with a razor blade in a Petri dish with $2 \mathrm{ml}$ nuclear isolation buffer supplemented with DAPI $(2 \mu \mathrm{g} / \mathrm{ml})$ (Sliwinska 2002). After chopping the suspension was passed through a $35 \mu \mathrm{m}$ mesh nylon filter. For each sample, 5000-10000 nuclei were analyzed directly after preparation using a Beckman Coulter Cell Lab Quanta TM SC flow cytometer. Fluorescence was collected using a 550-nm Dichroic LP and 465-nm BP. Selected haploids were vegetatively propagated in order to obtain six clones of each genotype. 


\section{Testing of haploid clones}

Haploid clones were simultaneously tested for resistance to Th. basicola and TSWV after transfer from tissue culture to soil. The tests and screening of haploid plants for disease symptoms followed the protocols as described above.

\section{Detection of markers linked to TSWV resistance}

Detection of markers was preceded by isolation of DNA carried out according to the methodology described by Czubacka and Doroszewska (2010). DNA was amplified by polymerase chain reaction (PCR). The ACT/CTA268 AFLP SCAR marker previously determined to be closely associated in coupling with the $N$. alata-derived gene for resistance to TSWV present in cultivar Polalta (Moon and Nicholson 2007) was used in this study. The ACT/CTA268 marker uses a pair of primers (CTGATCGTTCCAGCAGGTTCTTAT, GGAGCTATTTCCAGACACGAA) to generate two PCRamplified products (161 and $200 \mathrm{bp}$ ) in genotypes carrying the TSWV resistance gene from Polalta and one product (200 bp) in genotypes that do not poses that gene. The amount of $1 \mu \mathrm{l}$ plant DNA (approximately $20 \mathrm{ng} / \mu \mathrm{l}$ ) was added to the mixture containing 1.9 units of Taq polymerase (Fermentas) and 4.5 pmol of each primer per $20 \mu \mathrm{l}$ reaction, 1.5x PCR buffer, $2 \mathrm{mM} \mathrm{MgCl}, 312.5 \mu \mathrm{M}$ dNTPs. The PCR was done in a termocycler using the following amplification procedure: for $2 \mathrm{~min}$ at $94^{\circ} \mathrm{C}$ followed by 30 cycles: $30 \mathrm{~s}$ at $94^{\circ} \mathrm{C}, 30 \mathrm{~s}$ at $55^{\circ} \mathrm{C}, 40 \mathrm{~s}$ at $72^{\circ} \mathrm{C}$ and a final elongation step $5 \mathrm{~min}$ at $72^{\circ} \mathrm{C}$. The products of PCR were analysed by electrophoresis in $2 \%$ agarose gels in $1 \mathrm{x}$ TBE buffer $(100 \mathrm{mM}$ Tris, $90 \mathrm{mM} \mathrm{H}_{3} \mathrm{BO}_{3}, 1 \mathrm{mM}$ EDTA, $\mathrm{pH} \mathrm{8.5)} \mathrm{at} \mathrm{7-10} \mathrm{V/cm.}$ PCR analysis was done on 40 plants of $F_{1}$ generation, 242 haploids, as well as on ten plants of resistant Polalta and susceptible K326.

\section{Statistics}

The chi-square test with one degree of freedom was performed to assess the inheritance of resistance to Th. basicola and TSWV in the haploid population obtained from the $F_{1}$ hybrid WGL $3 \times$ PW-834.

\section{Results}

As a result of mating WGL 3 to PW-834 $\mathrm{F}_{1}$ hybrids were obtained that showed a general habit intermediate between that of each parental line. The hybrids showed some deformations such as veinal thickening and sometimes irregular venation.

Root inoculations performed in the greenhouse revealed that all Wislica plants developed typical black root rot symptoms which was accompanied by the presence of Th. basicola spores on the roots (Table 1). Although cultivar Polalta is generally considered as susceptible a small percentage of inoculated plants did not show any infection symptoms. In the line PW-834 the reaction to Th. basicola was generally similar to that observed for Polalta with two plants out of forty failing to develop disease lesions. Macroscopic assessment of the line WGL 3 and of the $F_{1}$ hybrid WGL $3 \times$ PW-834
Table 1. Resistance to Thielaviopsis basicola in the $\mathrm{F}_{1}$ hybrids WGL $3 \times$ PW-834, haploid clones of WGL $3 \times$ PW-834, parental lines WGL 3, PW-834 and reference cultivars of tobacco

\begin{tabular}{|c|c|c|c|c|}
\hline \multirow[b]{2}{*}{ Genotype } & \multicolumn{4}{|c|}{ Number of plants } \\
\hline & Tested & $\begin{array}{c}\text { Resistant/ } \\
\text { Susceptible to } \\
\text { Th. basicola }\end{array}$ & $\begin{array}{c}\text { Resistant/ } \\
\text { Susceptible to } \\
\text { TSWV }\end{array}$ & $\begin{array}{c}\text { Resistant to } \\
\text { Th. basicola } \\
\text { + TSWV }\end{array}$ \\
\hline WGL 3 & 40 & $40 / 0$ & $0 / 40$ & 0 \\
\hline PW-834 & 40 & $2 / 38$ & $40 / 0$ & 2 \\
\hline Polalta & 20 & $2 / 18$ & $20 / 0$ & 2 \\
\hline Wislica & 20 & $0 / 20$ & $0 / 20$ & 0 \\
\hline $\begin{array}{c}\mathrm{F}_{1} \text { WGL } 3 \times \\
\mathrm{PW}-834\end{array}$ & 40 & $40 / 0$ & $40 / 0$ & 40 \\
\hline $\begin{array}{c}\mathrm{H}^{\mathrm{a}} \text { WGL } 3 \times \\
\text { PW- } 834\end{array}$ & 242 & $132 / 110$ & $30 / 212$ & 24 \\
\hline
\end{tabular}

$\mathrm{H}^{\mathrm{a}}$-haploids of $\mathrm{F}_{1}$ hybrid WGL $3 \times \mathrm{PW}-834$

Table 2. Effectiveness of androgenesis of the $F_{1}$ hybrids WGL $3 \times$ PW-834 of tobacco

\begin{tabular}{lccccc}
\hline \hline \multicolumn{2}{c}{ Number of anthers } & \multirow{2}{*}{ Androgenetic } & \multicolumn{3}{c}{ Number of plants } \\
\cline { 4 - 6 } Cultured & Responded & reaction (\%) & $\begin{array}{c}\text { /Anther } \\
\text { (range) }\end{array}$ & Obtained & $\begin{array}{c}\text { Haploids } \\
(\%)\end{array}$ \\
\hline 510 & 25 & 4.9 & $(2-24)$ & 244 & $242(99.2)$ \\
\hline
\end{tabular}

confirmed the lack of Th. basicola spores on the roots, and both assessments taken jointly were considered as indicative of resistance to Th. basicola. The presence of TSWV virus was confirmed in the susceptible cultivar Wislica and in the line WGL 3.

All plants of the $\mathrm{F}_{1}$ hybrid WGL $3 \times \mathrm{PW}-834$ were identified as resistant to both diseases and served as anther donors. Embryos were obtained in the anthers after forty days of culture. Androgenetic response to culture was very low and amounted to $4.9 \%$ of plantlets/embryos producing anthers (Table 2). There was a considerable variation among individual anthers for the number of emerged plantlets ranging from 2 to 24. Finally, the flow cytometry of 244 regenerated plants showed that 242 were haploids and two were diploids.

Haploid plants were simultaneously tested for BRR and TSWV resistance. When visually observed for necrotic lesions $132(54.5 \%)$ genotypes were found to have no injuries (Table 1). The same 242 haploids were screened for resistance to TSWV. Only thirty (12.4\%) genotypes were found to be resistant. The remaining 212 genotypes revealed systemic symptoms of TSWV infection and a high level of virus as detected by ELISA. In this case the ratio of resistant to susceptible plants amounted to $1: 7.06$ (Table 3).

The value of the frequency of resistance to Th. basicola and TSWV in haploid clones of the $\mathrm{F}_{1}$ hybrid WGL $3 \times \mathrm{PW}-$ 834 are presented in Table 3 . In case of inheritance of resistance to Th. basicola chi-square test revealed a close fit to a $1: 1$ ratio of resistant to susceptible for haploid population. The frequency of TSWV resistant to susceptible individuals 
Table 3. Resistance to Th. basicola and TSWV in haploid clones of tobacco (Nicotiana tabacum) derived from the $\mathrm{F}_{1}$ hybrid WGL $3 \times$ PW-834

\begin{tabular}{lcccccc}
\hline \hline $\begin{array}{l}\text { Reaction to } \\
\text { infection: }\end{array}$ & $\begin{array}{c}\text { Frequency } \\
\text { of resis- } \\
\text { tance (\%) }\end{array}$ & $\begin{array}{c}\text { Expected } \\
\text { ratio } \\
\text { resistant: } \\
\text { susceptible }\end{array}$ & $\begin{array}{c}\text { Observed } \\
\text { ratio } \\
\text { resistant: }\end{array}$ & $\mathrm{X}^{2}$ & $P$-value \\
\hline Th. basicola & 54.5 & $1: 1$ & $1.2: 1$ & 2.0 & 0.15730 \\
\hline TSWV & 12.4 & $1: 1$ & $1: 7.1$ & 136.86 & $1.9953^{*} 10^{-31}$ \\
\hline
\end{tabular}

Table 4. Segregation of Th. basicola resistance within the haploid population resistant to TSWV derived from the $\mathrm{F}_{1}$ hybrid WGL $3 \times$ PW-834

\begin{tabular}{cccccc}
\hline \hline $\begin{array}{c}\text { No. of } \\
\text { haploids }\end{array}$ & $\begin{array}{c}\text { No. of haploids } \\
\text { resistant to } \\
\text { Th. basicola } \\
\text { + TSWV }\end{array}$ & $\begin{array}{c}\text { Expected } \\
\text { ratio } \\
\text { resistant: } \\
\text { susceptible }\end{array}$ & $\begin{array}{c}\text { Observed } \\
\text { ratio } \\
\text { resistant: } \\
\text { susceptible }\end{array}$ & $X^{2}$ & $P$-value \\
\hline 30 & 24 & $1: 1$ & $4: 1$ & 10.8 & 0.001 \\
\hline
\end{tabular}

diverged significantly from a $1: 1$ ratio expected, in case of a dominant monogenic mode of inheritance. The segregation of Th. basicola resistance factor within the haploid population resistant to TSWV deviated substantially from the expected value (Table 4). From the 30 haploids identified as having TSWV, 24 of them also had BRR resistance. The chi-square value and $\mathrm{P}<0.05$ excluded the hypothesis that high percentage of BRR resistant individuals reflect normal variability.

PCR-amplified products using the primers for the ACT/ CTA268 SCAR marker included two fragments (161-bp and 200-bp) in all plants of Polalta, in all 40 plants of the $F_{1}$ generation and in 30 haploid plants/clones in which the resistance was previously confirmed in DAS-ELISA tests. Only one fragment (200 bp) was found in K326 and in the haploid plants which showed susceptibility upon exposure to TSWV (Fig. 1).

In general, twenty four (10.7\%) of the tested haploids did not show either black root rot lesions or TSWV symptoms and were thus found as combining resistance to Th. basicola and TSWV.

\section{Discussion}

The rate of androgenetic induction observed in this study was low and clearly departed from that reported for inbred tobacco varieties (Nitsch and Nitsch 1969). Low rate of haploid production from cultured anthers may be due to the physiological status of anther-donor plants or may be genotypedependent (Forster et al. 2007). In this study the genotyperelated factor/s seems to be a more plausible cause. Polalta is notorious for producing abnormal phenotypes, especially in a heterozygous condition (Moon and Nicholson 2007). It is thus possible that the genes responsible for aberrant morphology may have affected the vigour and survival rate of male gametophytes generated by anther culture. A very de-

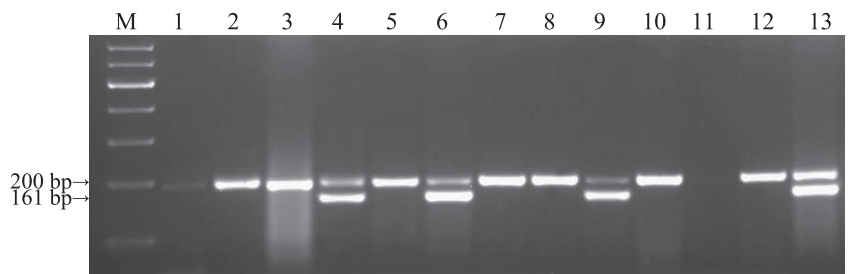

Fig. 1. A SCAR marker S-ACT/CTA268 (161 bp indicated by arrow) linked with TSWV resistance gene. Lane M-100bp DNA ladder; lane $1,2,3,5,7,8,10$ susceptible haploids from WGL $3 \times \mathrm{PW}-834 \mathrm{~F}_{1}$ hybrids; lane 4, 6, 9 resistant haploids; lane 11 negative control (water); lane 12 susceptible K326; lane 13 positive control Polalta

pressed rate of haploid induction was observed in cultured anthers produced by Polalta and cv. K326 hybrids (Moon and Nicholson 2007). In another study, the culture of anthers from an $F_{1}$ hybrid of Polalta with cv. Wislica also gave low rate of haploid survival coupled with morphological abnormalities of the surviving plants both in vitro and when grown in the greenhouse (Laskowska and Berbec 2010). In both reports, the investigators linked haploid inviability and phenotypic aberrations to the deleterious impact of genetic material introduced from Polalta in association with the TSWV resistance gene.

Cloning of the haploids and subsequent testing for resistance of the clones was found to be a very efficient and rapid approach. In the case of black root rot resistant genotypes were selected as early as 30 days after inoculation. The ratio of resistant to susceptible phenotypes (54.5\%) within the haploid population coupled with the absence of BRR symptoms in the $\mathrm{F}_{1}$ donor plants shows a very good fit with the expected results for gamete segregation in the dominant monogenic type of inheritance. Those results give evidence that the resistance to black root rot derived from N. glauca and present in the line WGL 3 follows the same pattern of inheritance as the widely used resistance from another Nicotiana species N.debneyi (Bai et al. 1996).

In the case of resistance to TSWV the observed ratio of resistant vs. susceptible haploid genotypes was wide off the mark from $1: 1$ if the dominant monogenic hypothesis is assumed. Actually, the reports on the type of inheritance of that resistance factor are somewhat ambiguous. The most recent one (Laskowska and Berbec 2010) unequivocally states that the resistance is dominant monogenic. Likewise, Moon and Nicholson (2007) stated, after Yancheva (1990), that resistance from Polalta is inherited as single monogenic and that assumption is tacitly assumed in their report. Much earlier, Kennedy and Nielsen (1993) were inclined to the two-gene based explanation of the observed segregation patterns. Those discrepancies may have been in some way related to the survival of gametes/embryos carrying the TSWV resistance gene or the genes closely linked to it, an issue discussed earlier in the section. Alternatively, differences and discrepancies in the observed segregation patterns could be attributed to irregular expression of the Polaltaderived resistance gene. 
However, the latter explanation was refuted by the results obtained in this study from the screening for the presence of the SCAR marker linked to Polalta-derived gene for TSWV resistance developed by Moon and Nicholson (2007). In this study the SCAR marker was detected only in the genotypes the resistance of which was assessed visually and confirmed by ELISA. Thus, the marker-assisted analysis of TSWV resistance performed in this study and the previous results by the creators of the SCAR marker Moon and Nicholson (2007) indicate that the Polalta-derived resistance to TSWV per se is expressed faithfully and regularly. The observed irregularities in the inheritance of that resistance are better explained by e.g. the deleterious action of the genes flanking the actual resistance gene (Moon and Nicholson 2007), the action which resulted in producing non-viable or noncompetitive phenotypes.

The inheritance analysis of Th. basicola resistance within population of haploids resistant to TSWV was performed. Assuming that TSWV and BRR resistance genes are inherited independently, the obtained results do not coincide with the expected ratio. The relatively high percentage of haploids resistant to $T h$. basicola may result from a certain level of resistance to BRR of the initial line PW-834, derived indirectly from wild tobacco N. alata (Gajos 1987).

In conclusion, our results give evidence that resistance to two important diseases of tobacco: resistance to TSWV from cv. Polalta, and N. glauca-derived resistance to black root rot, can be successfully combined in one genome. They also provided additional data on the nature and inheritance patterns of the two sources of resistance. The obtained haploid genotypes combining a gene/s for black root rot resistance and gene for TSWV resistance provide a starting material for developing inbred lines to be used in commercial breeding of tobacco.

\section{Literature Cited}

Bai,D.P., R.Reeleder and J.E.Brandle (1996) Production and characterization of tobacco addition lines carrying $N$. debneyi chromosomes with a gene for resistance to black root rot. Crop Sci. 36: $852-857$.

Berbec,A. (2006) Field performance of Poland's new flue-cured tobacco varieties resistant to Chalara elegans. CORESTA Congress, AP 22. Full text on CORESTA CD-ROM, 11 rue du Quatre Septembre 75002 Paris, France.

Clark,M.F. and A.N.Adams (1977) Characteristics of the microplate method enzyme-linked immunosorbent assay for the detection of plant viruses. J. Gen. Virol. 34: 475-483.

Clayton,E.E. (1969) The study of resistance to the black root rot disease of tobacco. Tob. Sci. 13: 30-37.

Czubacka,A. and T.Doroszewska (2010) Combination of different sources of resistance to PVY in tobacco doubled haploids. CORESTA Joint Study Groups Meeting 2010, Edinburgh AP-08.

Daughtrey, M.L., R.K.Jones, J.W.Moyer, M.E.Daub and J.R.Baker (1997) Tospoviruses strike the greenhouse industry. Plant Dis. 81: 1220-1230.

Florczak,K. (1991) Resistance of the cultivars and hybrids of tobacco to Thielaviopsis basicola (Berk. and Br.) Ferraris, in the light of in- vestigations delved from 1979 to 1988 . Biul.CLPT 3-4: 37-44.

Forster,B.P, E.Heberle-Bors, K.J.Kasha and A.Touraev (2007) The resurgence in higher plants. Trends in Plant Sci. 12: 368-375.

Gajos,Z. (1981) Transmission of resistance to Tomato spotted wilt virus from Nicotiana alata Link and Otto to N. tabacum by crossing both species. Biul. CLPT 1: 3-24.

Gajos,Z. (1987) Polalta, the first Polish tobacco variety resistant to Tomato spotted wilt virus was released for regional experimentation and propagation. Wiad. Tytoniowe 31: 11-17.

Gayed,S.K. (1972) Host range and persistence of Thielaviopsis basicola in tobacco soil. Can. J. Plant Sci. 52: 869-873.

Hamada,K., I.Masayoshi, A.Tanaka and H.Watanabe (2001) Potato Virus Y-Resistance in the progeny of haploid mutants obtained by the culture of Nicotiana tabacum L. anthers exsposed to ion beams. Plant Biotechnol. 18: 251-257.

Kennedy,B.S. and M.T.Nielsen (1993) Characterization of Tomato spotted wilt virus (TSWV) resistance in the tobacco cultivar Polalta. Phytopathology 83: 1420.

Laskowska,D. and A.Berbec (2005) Cytology and fertility of viable hybrids of Nicotiana tabacum L. cv. TB-566 with $N$. alata Link and Otto. J. Appl. Genet. 46: 11-18.

Laskowska,D. and A.Berbec (2010) TSWV resistance in DH lines of tobacco (Nicotiana tabacum L.) obtained from a hybrid between Polalta and Wislica. Plant Breed. 129: 731-733.

Menchey,E.K. and M.Aycock (1998) Anther-derived dihaploids for lodging improvement in tobacco. Crop Sci. 38: 698-701.

Moon,H. and J.S.Nicholson (2007) AFLP and SCAR markers linked to Tomato spotted wilt virus resistance in tobacco. Crop Sci. 47: 1887-1894.

Nitsch,J.P. and C.Nitsch (1969) Haploid plants from pollen grains. Science 163: 85-87.

Punja,Z.K. and L.J.Sun (1999) Morphological and molecular characterization of Chalara elegans (Thielaviopsis basicola), cause of black root rot on diverse plant species. Can. J. Bot. 77: 1801-1812.

Rothrock,C.S. (1992) Influence of soil temperature, water, and texture on Thielaviopsis basicola and black root rot on cotton. Phytopathology 82: 1202-1206.

Samek,D. and F.Jankowski (1987) Studies on the method of evaluating the degree of susceptibility of tobacco varieties to black root rot (Thielaviopsis basicola Ferr.) under greenhouse conditions. Biul. CLPT. 1: 91-104.

Sliwinska,E. (2002) Wykorzystanie cytometrii przepływowej w biotechnologii roslin. Biotechnologia 1: 122-128.

Thalmann, R., K.Kaufmann and Ch.Struck (2008) Black root rot on lupinus - an early species-specific detection of the pathogen Thielaviopsis basicola. Gesunde Pflanzen 60: 67-75.

Trojak-Goluch,A. and A.Berbec (2005) Potential of Nicotiana glauca (Grah.) as a source of resistance to black root rot Thielaviopsis basicola (Berk. and Broome) Ferr. in tobacco improvement. Plant Breed. 124: 507-510.

Trojak-Goluch,A. and A.Berbec (2011) Growth, development and chemical characteristics of tobacco lines carrying black root rot resistance derived from Nicotiana glauca (Grah.). Plant Breed. 130: 92-95.

Tsakiridis, J.P. and G.V.Gooding (1972) Tomato spotted wilt virus in Greece. Phytopatol. Mediterranea 11: 42-47.

Walker,D.R. and M.K.Aycock (1994) Development of anther-derived dihaploids to combine disease resistance in Maryland tobacco. Crop Sci. 34: 335-338.

Yancheva,A. (1990) Possibility of transferring combined resistance to Tomato spotted wilt virus and Thielaviopsis basicola to intervarietal hybrids of tobacco. Genet. Sel. 23: 194-199. 